\title{
A personal reflection koha, and how ako and communication strategies support the practice of Pacific research models and frameworks at Te Wānanga o Aotearoa
}

Te Wānanga o Aotearoa is first and foremost a uniquely Māori learning environment, as a Pasifika educator who feels privileged in this space, it has become prominent to me more than ever to understand what my Pacific practice means in relation theory; and how my practice can complement our institutional values of Te Aroha, Te Whakapono, Ngā Ture and Kotahitanga. These values are embedded in our institution and communicate the actions to achieve successful outcomes for our tauira (Te Wananga o Aotearoa, n.d).

Embarking on the New Zealand Certificate in Adult \& Tertiary Teaching with Te Wānanga o Aotearoa, was an opportunity for me to reflect and critically analysis my teaching practice. The programme led by Sheryl Waru, meant that our space and content was always exciting, innovative, creative and nurturing to the diversity of talent and skills my colleagues had to offer. Here was where I understood Ako as a teaching and learning relationship that is grounded in the principle of reciprocity. This was linked to our paper 'Koha', koha refers to gift, present, offering, donation, contribution especially one maintaining social relationships and has 
connotations of reciprocity (Moorfield, 2011). From my understanding and experience koha meant the acknowledgement through reciprocity, in whichever form it may take physical or spiritual it is an exchange and acknowledgment of the other. Koha mai the action to receive and koha atu to action give are two significant acts of kindness that maintain and sustain a social relationship. Upon reflection of my teaching practice koha atu could be seen as the skills and knowledge delivery from the educator placed in the learner's kite, and koha mai, would be the knowledge and each learner will reciprocate in the classroom from their backgrounds and experiences. This understanding of koha forced me to think in detail about the type of learning strategies that took place in my classroom, more specifically what values underpinned this practice.

In terms of my personal Koha to Te Wananga o Aotearoa, I wanted to create a simple teaching resource that drew upon my knowledge of the Pacific research models and frameworks, and how these were demonstrated in my teaching practice. To koha atu and create a guide of understanding that was accessible to educators who were willing to learn about indigenous models of practice and in turn, koha mai contribute more effective relationships and ako experiences with leaners.

The four ako communication strategies presented Fonofale, Tivaevae, Talanoa and Teu le Vã were a part of an evaluation of my lessons and demonstrate a reflection of strategies that can be applied by most educators. Though not explicit the Pacific values presented align with the values of Te Aroha, Te Whakapono, Ngā Ture and Kotahitanga thus fostering a Māori learning environment. The examples presented are education-specific and is a useful resource and starting point for educators to further research Indigenous worldviews, knowledge and cultural frameworks. 
In summary, my teaching environment is a space where I am responsible for my learners to ensure they are aware of who I am, my role and my purpose, to equip my learners with the right skills, knowledge and understandings for them to carry out the required task to complete. The learner's expectation of me is to trust in my service, and the ability to lead a tuakana teina relationship thus creating a safe learning environment. Respect and trust are key values for both teacher and learner, my expectations from the learner are to acknowledge my role and to trust my capability to reciprocate the koha of knowledge. 


\section{References}

Ministry of Education. (2018). Tapasā: Cultural competencies framework for teachers of Pacific learners. Ministry of Education New Zealand Te Tāhuhu o te Mātauranga. https://pasifika.tki.org.nz/Tapasa

Moorfield, J. C. (2011). Te Aka-Māori-English, EnglishMāori dictionary. Auckland, New Zealand: Pearson.

Te Wananga o Aotearoa. (n.d). Ngā Uara - Our Mission, Vision, and Values. https://www.twoa.ac.nz/tewhare/nga-uara 